\title{
Antagonistic Activity of Pseudomonas Fluorescens Against Fusarium Oxysporum f. sp. Nievum Isolated from Soil Samples in Palestine
}

\author{
Mazen Salman ${ }^{1}$, Nabil Shahin ${ }^{1}$, Nawaf Abu-Khalaf ${ }^{1}$, Mohammad Jawabrih ${ }^{1}$, Basima Abu Rumaileh ${ }^{1}$, Ruba \\ Abuamsha $^{2} \&$ Sameer A. Barghouthi ${ }^{3}$ \\ ${ }^{1}$ College of Agricultural Sciences and Technology, Palestine Technical University-Kadoorie (PTUK), Tulkarm, \\ State of Palestine \\ ${ }^{2}$ National Agriculture Research Centre (NARC), Ministry of Agriculture, Qabatya, Jenin, State of Palestine \\ ${ }^{3}$ Department of Medical Laboratory Sciences, Faculty of Health Professions, Al Quds University, Jerusalem, State \\ of Palestine
}

Correspondence: Mazen Salman, College of Agricultural Sciences and Technology, Palestine Technical University-Kadoorie (PTUK), Tulkarm, State of Palestine. E-mail: salman_mazen@daad-alumni.de

Received: January 23, 2017

doi:10.5539/jps.v6n2p1
Accepted: February 20, 2017 Online Published: March 6, 2017

URL: https://doi.org/10.5539/jps.v6n2p1

\begin{abstract}
Watermelon is an important summer crop in Palestine, for several decades filling the needs of local market and some Arab countries. The yield of watermelon decreased dramatically in recent years due to severe infections with the soil borne fungal pathogen Fusarium oxysporum $f$. sp. niveum (FON). Soil fumigation with methyl bromide was commonly applied by Palestinian farmers until it was recently legally banned. Different control mechanisms were not feasible to overcome problems caused by the disease resulting in decreased watermelon cultivation in Palestine for the past 30 years. In this work, we have experimentally shown that Pseudomonas fluorescens was efficient in controlling FON infection and allowing normal seedling growth of both the root and shoot systems. Field experiments are necessary to further confirm the efficacy of biocontrol application.
\end{abstract}

Keywords: Biological Control, Watermelon, Fungi, Bacteria

\section{Introduction}

Watermelon (Citrullus lanatus L.) is an economically important vegetable crop in many parts of the world. In Palestine, it is one of the most important summer fruit crops. According to FAOSTAT (2014), the watermelon cultivated area was estimated to be 356 ha during the period from 2001-2008 with an average yield of 13,777 tons. In the following years, the watermelon area decreased by more than $65 \%$ and the total annual production was reduced by more than $75 \%$ (FAOSTAT, 2014). A number of reasons caused the dramatic decline in watermelon cultivation, of which Fusarium Wilts caused by formae speciales of Fusarium oxysporum that are generally considered host specific (Martyn, 2012; Ren et al., 2015; Meyer et al., 2016). Fusarium oxysporum f. sp. niveum (FON) is one of the most severe diseases in watermelon and a major limiting factor for watermelon production in the world (Martyn \& McLanghlin, 1983; Peng et al., 2013). Due to high infestation rates of the disease in different regions in Palestine, farmers have abandoned growing watermelon. The use of fungicides is not always feasible due to economic and ecological reasons.

Currently, no effective fungicides or chemical disinfectants are available because FON can generate thick-walled chlamydospores that are highly resistant to soil fumigation (Besri, 2008; Peng et al., 2013). FON can survive in soil as saprophyte for many years (Notz, Maurhofer, Dubach, Haas, \& Defago, 2002). Therefore, watermelons can only be replanted in locations with infected soil, after FON has been eradicated by preplan treatments with soil fumigants. However, the most effective soil fumigant, methyl bromide, has been phased out, and FON can transform itself into thick-walled chlamydospores, highly resistant to chemical fumigation (Lin, Chen, Liou, Huang \& Chang, 2009), leaving hardly any means to control the soilborne FON safely, economically and effectively (Ren et al., 2015).

With increasing public awareness of the environmental implications of the extensive use of fungicides in agricultural practices, alternative strategies for the control of plant disease are being sought (Weller, 1988; Ellis et al., 1999). Biological control using antagonistic microorganisms alone, or as supplements to minimize the use 
of chemical pesticides in a system of integrated plant disease management, has become more important in recent years (Hwang, 1993; Mao, Lewis, Hebber, \& Lumsden, 1997).

Soilborne, non-pathogenic fast growing bacteria that are capable of antagonizing fungal phytopathogens might represent first choice biocontrol method. They show great promise with respect to protecting plant roots from fungal-induced diseases (O'Sullivan \& Ogara, 1992; Walsh, Morrissey, \& O'Gara, 2001). These bacteria are known by several generic names, including biological control agents (BCAs), plant growth promoting rhizobacteria (PGPR) and biopesticides (Walsh et al., 2001). The aim of this study was to test the activity of $P$. fluorescens isolate against the watermelon fungal pathogen $F$. oxysporum f. sp. nievum (FON).

\section{Methods}

\subsection{Isolation of FON Plant Pathogens}

Soil and plant samples naturally infested with FON were used for the isolation of pathogenic strains of the fungus. Isolation from soil samples was conducted using the soil dilution plate technique modified from Nishimura (2007). One gram of soil was suspended in $99 \mathrm{ml}$ of $0.05 \%$ water agar. Serial dilutions $\left(10^{-3}, 10^{-4}\right.$ and $10^{-5}$ ) were prepared and $100 \mu \mathrm{l}$ from each solution were spread on selective medium for FON isolation; selective medium was prepared as described by Leslie and Summerell (2006).

For isolation of the pathogen from plant materials and debris, samples were washed thoroughly under running tap water, blotted to remove excess water, cut into $0.5 \mathrm{~cm}$ pieces that were placed on the selective medium.

\subsection{Selection of Biological Control Agents (BCAs) to FON}

Bacteria were isolated from healthy and infected watermelon plants as well as from infested and non-infested soil samples. Bacterial extracts were suspended in $0.085 \% \mathrm{NaCl}$, diluted serially and $100 \mu \mathrm{l}$ were spread on Nutrient Agar media supplemented with $50 \mu \mathrm{g} \mathrm{ml}^{-1}$ cyclohexamide.

Four-day old cultures of FON grown on 7-mm diameter disks were placed centrally on potato dextrose agar (PDA) plates were used as targets for bacterial mediated antagonism. Bacterial suspensions $\left(\sim 5 \times 10^{9} \mathrm{cfu} \mathrm{ml}^{-1}\right)$ in $20 \mu \mathrm{l}$ of $24 \mathrm{hrs}$ old broth cultures were placed on $0.5 \mathrm{~cm}$ sterile paper disks. The assembled test cultures were incubated for $48 \mathrm{hrs}$ at $22^{\circ} \mathrm{C}$ and inhibition of mycelial growth was noted. Bacteria that inhibit fungal growth were selected for further greenhouse studies. Identification of $P$. fluorescens was done as mentioned in Barghouthi (2010).

\subsection{Pathogenicity of Bacteria to Host Plant (Wtermelon)}

In order to test whether the selected bacteria were pathogenic to host plants, 2-3 true leaf stage plants (grown in peat moss vermiculite mix $2: 1, \mathrm{v} / \mathrm{v}$ ) were treated by root drench with different concentrations of bacterial suspensions $\left(10^{7}-10^{9} \mathrm{cfu} \mathrm{ml}^{-1}\right)$. Control was done by treatment of seedlings with sterile water. Seedlings were incubated in climate rooms of $12 \mathrm{hrs}$ day length and day-night temperature of $26^{\circ} \mathrm{C}$ and $16^{\circ} \mathrm{C}$. Plant height, fresh and dry weights of root and shoot, and damage were assessed and recorded after the plant reached a stage of development of 4-5 true leaves (Montealegre et al., 2003).

The pathogenicity of bacterium was tested on watermelon seeds as well. Seeds were immersed in bacterial suspensions $\left(10^{7}-10^{9} \mathrm{cfu} \mathrm{ml}^{-1}\right.$ in $2 \%$ methylcellulose, $\left.\mathrm{pH} 7.0\right)$ for 60 seconds (Abuamsha, Salman, \& Ehlers, 2011). Seeds were sown in peat moss vermiculite mix $(2: 1, \mathrm{v} / \mathrm{v})$ at the above mentioned conditions. Measurements of time of emergence, heights and fresh and dry weights of shoots and roots were recorded when the seedling reached the 2-3 true leaf stage (Montealegre et al., 2003).

\subsection{Molecular Identification of Isolated Fusarium Spp}

Isolated fungal strains were identified using PCR according to the method of Z. Zhang, J. Zhang, Wang, and Zheng (2005). Specific primers for FON Fn-1 (5'-TACCACTTGTTGCCTCGGC-3') and Fn-2 (5'-TTGAGGAACGCGAATTAAC-3') were used to produce a 327 bp PCR product. PCR was performed in 25 $\mu 1$ reaction mixtures containing $1 \mu \mathrm{l}$ genomic DNA, $0.5 \mu \mathrm{M}$ primers, a $0.5-\mu 1$ mixture that contained $50 \mathrm{mM}$ of each dNTP, $2.5 \mu 110$ PCR buffer, $2 \mathrm{mM} \mathrm{Mg}^{2+}, 2.5 \mu \mathrm{l}$ 1\% BSA, $0.25 \mu \mathrm{l}$ Tw-20, and $1.25 \mathrm{U}$ of Taq DNA polymerase. Amplification was performed using PCR System DNA thermal cycler programmed for one cycle at $94^{\circ} \mathrm{C}$ for $5 \mathrm{~min}$, followed by 35 cycles at $94^{\circ} \mathrm{C}$ for $30 \mathrm{~s}, 54^{\circ} \mathrm{C}$ for $30 \mathrm{~s}$, and $72^{\circ} \mathrm{C}$ for $30 \mathrm{~s}$. A final 7 -min extension at $72^{\circ} \mathrm{C}$ was conducted. PCR products were separated on $1.5 \%$ agarose (in TAE buffer) for $60 \mathrm{~min}$ at $70 \mathrm{~V}$ and visualized after staining with ethidium bromide $(0.2 \mu \mathrm{g})$ under UV transilluminator.

\subsection{In Vitro Inhibition of Fungal Growth}

The antagonistic activity of bacteria against FON was determined using the dual culture technique (Salman, 
2010). Each bacterial strain was streaked on the center line of a PDA plate and incubated for $24 \mathrm{hrs}$ at $28^{\circ} \mathrm{C}$. Then two disks of FON grown for 4 days on PDA medium were placed about $3 \mathrm{~cm}$ apart from the bacterial streak. Cultures were then incubated at $22^{\circ} \mathrm{C}$ for $48 \mathrm{hrs}$. Control experiments used sterile distilled water instead of bacteria. The distance between the bacterial streaks was recorded and the effect of the bacteria was determined by measuring the inhibition zone of mycelial growth.

\subsection{Greenhouse Pot Experiments}

Watermelon (Citrullus lanatus (Thunb)) was used as the target test plant species. Seed treatment with the bacteria was done as mentioned above. For infesting soil with $F$. oxysporum sp. niveum, pots $(9 \mathrm{~cm}$ diameter; $\left.450 \mathrm{~cm}^{3}\right)$ were $66 \%$ filled with peat moss vermiculite mix $(2: 1, \mathrm{v} / \mathrm{v})$. Small agar pieces (1/16 of an agar plate; 3 ( $7 \mathrm{~mm}$ diameter) discs from plates grown with FON (4-days old) were placed on the soil surface of each pot. Subsequently, the inoculum of each pot was then covered with a top layer of soil. The pots with infested soil and control-non-infested soil were watered and incubated for 3-days under greenhouse conditions as mentioned above, before sowing five watermelon seeds per pot (Vogt \& Buchenauer, 1997). Disease development was recorded by examining a cross section of water melon stems after three weeks of sowing the seeds. During experimental period, all plants were fertilized weekly with commercial N:P:K (8:8:6) fertilizer.

\subsection{Statistical Analysis}

All experiments were done in triplicates and repeated three times. Statistical analysis was done using XIStat (Adinosoft). Significant differences were computed using ANOVA after Tukeys HSD test at $\mathrm{P}<0.05$.

\section{Results}

Six FON isolates (F161, F162, F163, F164, F241, and F243) were obtained from infected watermelon plants. All six isolates were shown to be FON based on PCR using $F$. oxysporum specific primers that produced a $327 \mathrm{bp}$ PCR amplicon (Fig. 1).

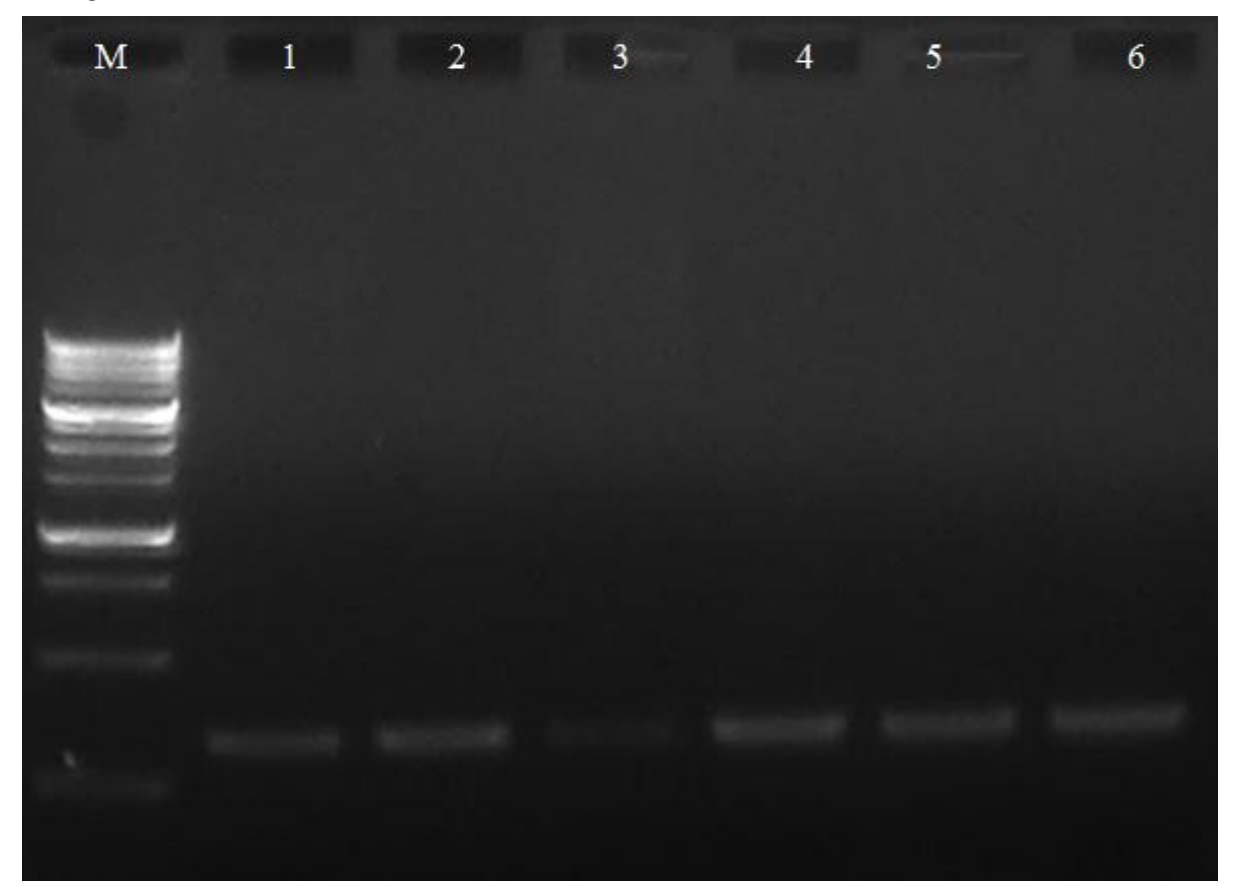

Figure 1. PCR products of 6 FON isolates F161 (lane 1), F162 (lane 2), F163 (lane 3), F164 (lane 4), F241 (lane 5) and F243 (lane 6) after amplification with FON specific primers Fn-1 and Fn-2. PCR products were separated on $1.5 \%$ agarose gel in $1 \mathrm{X}$ TAE buffer at $80 \mathrm{~V}$ for $1 \mathrm{~h}$. Lane $\mathrm{M}, 100 \mathrm{bp}$ marker.

All fungal isolates were detected in reinfected watermelon seedlings. However, only isolate F161 showed browning symptoms in cross sections of the seedlings (Fig. 2). The isolate was used for further studies to evaluate the efficacy of bacteria against the pathogen. Inhibition zones on PDA against FON isolates were obvious in the presence of $P$. fluorescens (Fig. 3). A large inhibition zone $(8 \mathrm{~mm})$ in the presence of the bacteria was significantly higher $(\mathrm{P}<0.05)$ against FON isolate F161 (Table 1). The lowest inhibition zone was recorded against FON isolate F162. 
Table 1. In vitro antagonistic effects of $P$. fluorescens isolates against six FON isolates on PDA medium.

\begin{tabular}{ccc}
\hline FON isolate & Inhibition distance $(\mathrm{mm})$ & Average diameter of FON $(\mathrm{mm})$ \\
\hline F161 & $8^{\mathrm{a}}$ & $9^{\mathrm{d}}$ \\
F163 & $5.4^{\mathrm{b}}$ & $11.5^{\mathrm{c}}$ \\
F241 & $5.4^{\mathrm{b}}$ & $13^{\mathrm{ab}}$ \\
F243 & $4.1 \mathrm{~b}^{\mathrm{c}}$ & $11.6^{\mathrm{bc}}$ \\
F164 & $3.6^{\mathrm{c}}$ & $13.1^{\mathrm{ab}}$ \\
F162 & $2.9^{\mathrm{c}}$ & $12.4^{\mathrm{bc}}$ \\
FON & $0^{\mathrm{d}}$ & $14.2^{\mathrm{a}}$ \\
\hline
\end{tabular}

Data with different letters in the same column are significantly different after ANOVA at $\mathrm{P}<0.05$ using Tukeys HSD test.

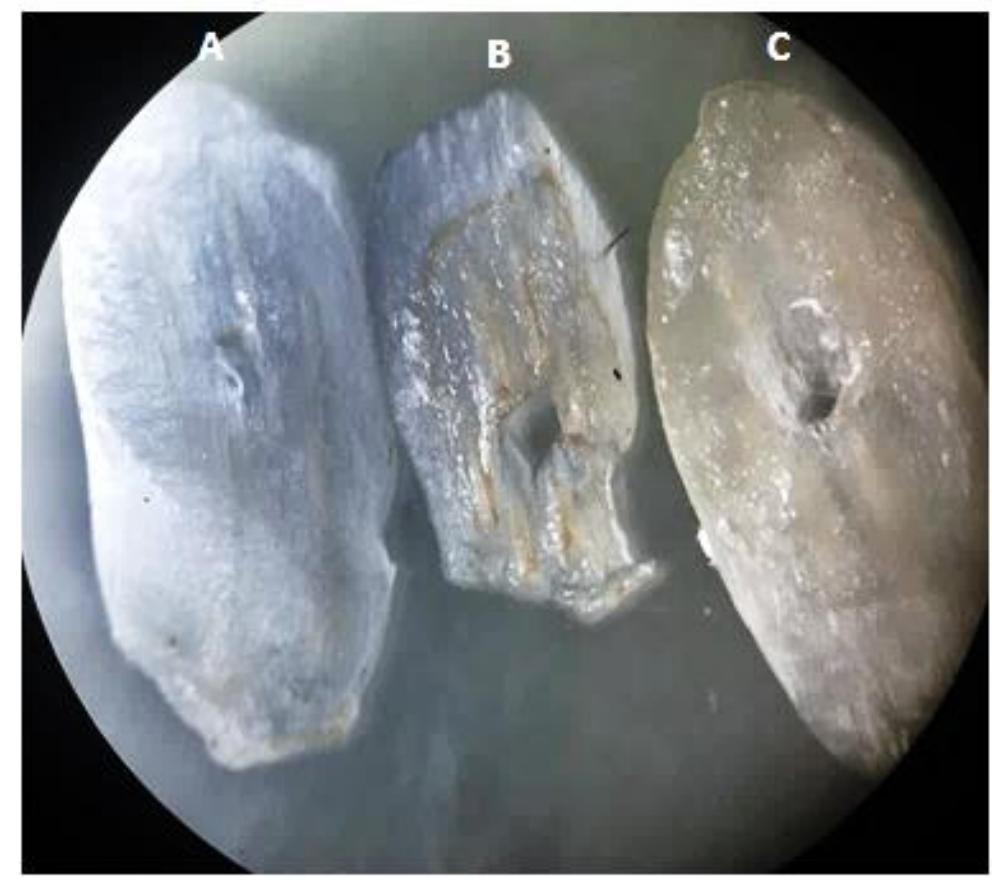

Figure 2. Stem Cross section showing vascular browning of watermelon stem (A) Control; (B) Infected with the FON isolate F161 and treated with of P. fluorescens and (C) Infected with FON isolate F161. Browning of tissue was due to fungal growth; indicating tissue infection. 

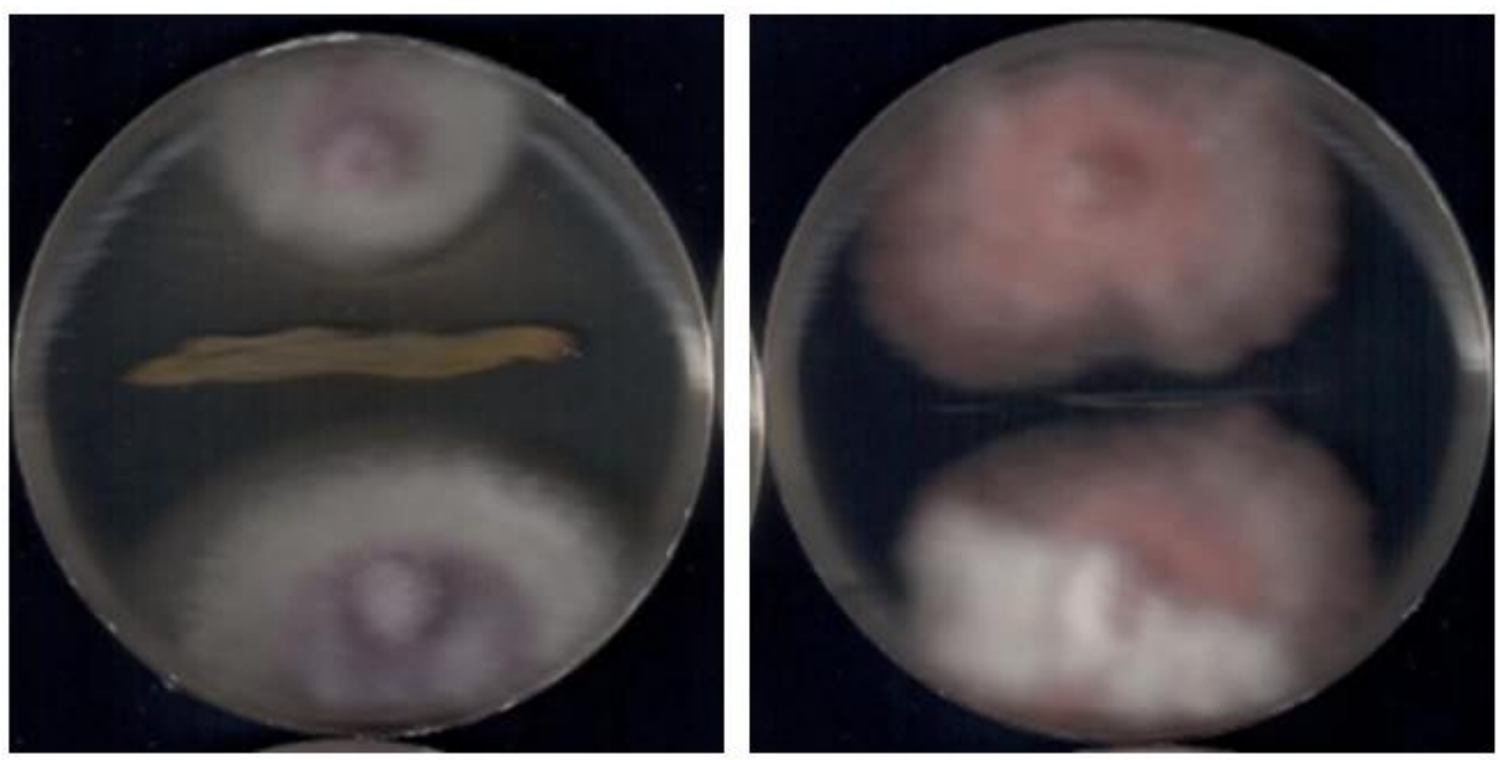

Figure 3. Inhibition caused by $P$. fluorescens against FON isolate 161 (left) on PDA medium.

Under pot experiments, watermelon seedling grown in the presence of the bacteria showed higher growth rates compared to control seedlings or seedlings infected with the pathogen (Fig. 4). Growth promotion effect of the bacteria was measured and the results proved the bacteria could enhance both fresh and dry weights of the plant (Table 2). Shoot fresh and dry weights of watermelon seedlings treated with the bacteria $(5.112 \pm 0.159$ and $1.03 \pm 0.105$, respectively) were significantly higher $(P<0.05)$ than that in the control seedlings $(3.40 \pm 0.448$ and $0.52 \pm 0.116$, respectively). Seedlings Infected with FON showed significantly lower $(\mathrm{P}<0.05)$ fresh shoot and root dry weights $(1.59 \pm 0.209$ and $0.31 \pm 0.068$, respectively). The same observations were recorded for dry shoot and root weights (Table 2).
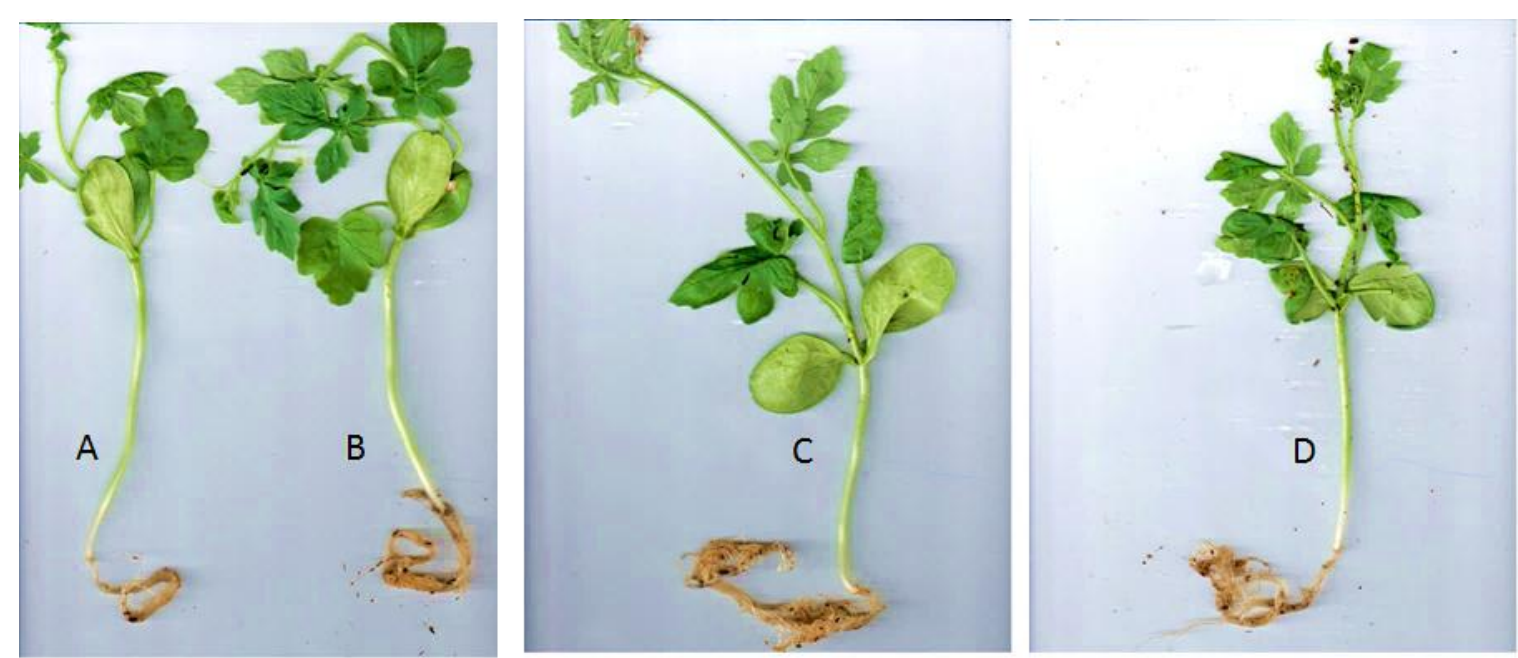

Figure 4. Seedlings of watermelon three weeks after sowing, (A) infected with FON isolate F161 (B) infected with isolate F161 and treated with P. fluorescens (C) treated only with P. fluorescens and (D) negative control, not treated. Notice that B, C, and D are well developed relative to A which is infected but not treated. 
Table 2. Fresh and dry weight of water melon seedling three weeks after sowing growth promotion effect of $P$. fluorescens on watermelon.

\begin{tabular}{lllll}
\hline & $\begin{array}{c}\text { Shoot fresh weight } \\
(\mathrm{g})\end{array}$ & $\begin{array}{c}\text { Shoot dry weight } \\
(\mathrm{g})\end{array}$ & $\begin{array}{c}\text { Root fresh weight } \\
(\mathrm{g})\end{array}$ & $\begin{array}{c}\text { Root dry weight } \\
(\mathrm{g})\end{array}$ \\
\hline Control & $3.40 \pm 0.448^{\mathrm{b}}$ & $0.20 \pm 0.047^{\mathrm{cd}}$ & $0.52 \pm 0.116^{\mathrm{bc}}$ & $0.03 \pm 0.006^{\mathrm{ab}}$ \\
P. fluorescens & $5.112 \pm 0.159^{\mathrm{a}}$ & $0.35 \pm 0.024^{\mathrm{ab}}$ & $1.03 \pm 0.105^{\mathrm{a}}$ & $0.05 \pm 0.012^{\mathrm{a}}$ \\
F161 & $1.59 \pm 0.209^{\mathrm{c}}$ & $0.08 \pm 0.009^{\mathrm{d}}$ & $0.31 \pm 0.068^{\mathrm{c}}$ & $0.01 \pm 0.008^{\mathrm{b}}$ \\
F161+P. fluorescens $^{\mathrm{b}}$ & $4.28 \pm 1.0138^{\mathrm{ab}}$ & $0.25 \pm 0.041^{\mathrm{bc}}$ & $0.64 \pm 0.140^{\mathrm{b}}$ & $0.03 \pm 0.017^{\mathrm{ab}}$ \\
\hline
\end{tabular}

Data with different letters in the same column are significantly different after ANOVA at $\mathrm{P}<0.05$ using Tukeys HSD test.

\section{Discussion}

In this study, it was found that some bacterial isolates were capable of preventing the growth of $F$. oxysporum $\mathrm{f}$. sp. niveum under in vitro conditions and in pot experiments, respectively. Reports on using bacteria as biocontrol agents against plant pathogens and pests have increased in recent decades. In this work, screening bacterial isolates for anti- $F$. oxysporum activity; 167 bacterial isolates were screened as described in methods section for anti $F$. oxysporum activity. The biological control approach of plant pathogens and diseases has been studied for many years, and the introduction of beneficial microorganisms into soil or the rhizosphere has been proposed for the biological control of soilborne crop diseases (Joffe, 1986; Burge, 1988; Cook, 1993). Many studies have been conducted on the application of antagonistic microbes, such as Pseudomonas spp., for the control of Fusarium wilt (Tu \& Chang, 1983; Duijff et al., 1999).

The ability of $P$. fluorescens to control the growth of $F$. oxysporum pathogenic isolates as represented by F161 was demonstrated in vitro assay and confirmed by pot experiments. The biocontrol activity of $P$. fluorescens observed in vitro experiments were reproduced in pot experiments.

P. fluorescens has shown great potential to controlling fungal infection. In addition, a significant $(\mathrm{P}<0.05)$ enhancement of the growth of control seedlings treated with the bacterium relative to untreated control indicates that in addition to controlling infection, $P$. fluorescens somehow stimulated seedling growth either by provision or solubilization of nutrients and/or further protection of plants against an invisible plant pathogen.

Seedling wet or dry weight produced consistent results that were significantly different for each applied combination; poor growth of infected seedlings, enhanced growth of $F$. oxysporum infected or non-infected seedlings receiving $P$. fluorescens treatment.

Wet or dry weight of shoot and root systems revealed that significant difference existed between infected and bio-controlled seedlings. The $P$. flueorescens protected seedlings; fresh shoot weight was $4.28 \pm 1.0138 \mathrm{~g}$ which was higher than the F161 infected seedlings vs. $1.59 \pm 0.209$ for the infected seedlings $(\mathrm{p}<0.05 ; \mathrm{n} \geqslant 9$ ). Protection allowed $>2.6$ folds enhancement in seedling shoot weight and enhanced growth $>1.6$ folds. $P$. fluorescens enhanced growth of seedlings in the absence of experimental infections possibly through the provision of other plant promoting factors or extended protection against unseen microbes or factors. The results are illustrated in Figs. 2-4 and Table 2.

Non-chemical strategies for the control of crop diseases are of considerable interest due to environmental and health concerns about the adverse effects of synthetic pesticides (Reuveni, 1995). Therefore, it is likely that there will be greater reliance on the use of microorganisms as antagonists of plant pathogens in the future (Hall, 1995; De Cal, Sztejnberg, Sabuquillo, \& Melgarejo, 2009). However, the spectrum of activity of microorganisms as biocontrol agents is usually narrower than that of chemical pesticides (Baker, 1991; Janisiewicz, 1996). In addition, the inconsistent performance of microorganisms in commercial agriculture has limited their use as agents for controlling plant pathogens (Backman, Wilson, \& Murphy, 1997; De Cal et al. 2009).

Application of Pseudomonas or its byproducts to field crops (before, during, and/or after sawing) such as watermelon and other similar crops that are afflicted by Fusarium, may improve the productivity and yields of such crops. Successful field biocontrol application will contribute to better agricultural methods. Furthermore, this method is cost effective, easily applicable and may accumulate beneficiary results on the long run; i.e. each successive year should be an improvement over the preceding year. Moreover, environmentally, it is a better choice than chemically based control methods. 


\section{Acknowledgments}

This research was supported by Palestine Technical University-Kadoorie (PTUK).

\section{References}

Abuamsha, R., Salman, M., \& Ehlers, R. U. (2011). Effect of seed priming with Serratia plymuthica and Pseudomonas chlororaphis to control Leptosphaeria maculans in different oilseed rape cultivars. European Journal of Plant Pathology, 130, 287-295. https://doi.org/10.1007/s10658-011-9753-y

Backman, P. A., Wilson, M., \& Murphy, J. F. (1997). Bacteria for biological control of plant diseases. In: Recheigl, N.A., Recheigl, J. E. (Eds.), Environmentally safe approaches to crop Disease control. CRC Lewis Publishers, Boca Raton, FL, pp. 95-109.

Baker, R. (1991). Diversity in biological control. Crop Protection, 10, 85-94. https://doi.org/10.1016/0261-2194(91)90054-U

Barghouthi, S. (2010). A Universal Method for the Identification of Bacteria Based on General PCR Primers. Indian Journal of Microbiology, 51(4), 430-444. https://doi.org/10.1007/s12088-011-0122-5

Besri, M. (2008). Cucurbits grafting as alternative to methyl bromide for cucurbits production in Morocco. Proceedings of the $14^{\text {th }}$ International Research Conference on Methyl Bromide Alternatives and Emissions Reduction, Orlando, pp. 60-61

Burge, M. N. (1988). The scope of fungi in biological control. In: Burge M.N. (Ed), Fungi in biological control systems. Manchester University Press, Manchester, 1-18

Cook, R. J. (1993). Making greater use of introduced microorganisms for biological control of plant pathogens. Annual Review of Phytopathology, 31, 53-80. https://doi.org/10.1146/annurev.py.31.090193.000413

De Cal, A., Sztejnberg, A., Sabuquillo, P., \& Melgarejo, P. (2009). Management Fusarium wilt on melon and watermelon by Penicillium oxalicum. Biological Control, 51, 480-486 https://doi.org/10.1016/j.biocontrol.2009.08.011

Duijff, B. J., Recorbet, G., Peter, A., Bakker, H. M., Loper, J. E., \& Lemanceau, P. (1999). Microbial antagonism at the root level is involved in the suppression of Fusarium wilt by the combination of nonpathogenic Fusarium oxysporum Fo47 and Pseudomonas putida WCS358. Phytopathology, 89, 1073-1079. https://doi.org/10.1094/PHYTO.1999.89.11.1073

Ellis, R. J., Timms-Wilson, T. M., Beringer, J. E., Rhodes, D., Renwick, A., Stevenson, L., \& Bailey, M. J. (1999). Ecological basis for biocontrol of damping-off disease by Pseudomonas fluorescens 54/96. Journal of Applied Microbiology, 87(3), 454-463. https://doi.org/10.1046/j.1365-2672.1999.00851.x

FAOSTAT, (2014). http://faostat3.fao.org/faostat-gateway/go/to/download/Q/QC/E

Hall, R. (1995). Challenges and prospects of integrated pest management. In: Reveuni, E. (Ed.), Novel approaches to integrated pest management. Lewis Publishers, CRC Press Inc., Boca Raton, FL, pp. 1-21

Hwang, S. F., Chakravarty, P., \& Prevost, D. (1993). Effects of rhizobia, metalaxyl, and VA mycorrrhizal fungi on growth, nitrogen fixation, and development of Pythium root rot of Sainfoin. Plant Disease, 77, 1093-1098. https://doi.org/10.1094/PD-77-1093

Janisiewicz, W. J. (1996). Ecological diversity, niche overlap, and coexistence of antagonists use in developing mixtures for biocontrol of postharvest diseases of apples. Phytopathology, 86, 473-479. https://doi.org/10.1094/Phyto-86-473

Joffe, A. Z. (1986). Fusarium species: their biology and toxicology. Wiley, New York.

Leslie, J. F., \& Summerell B. A. (2006). The Fusarium laboratory manual. Blackwell Publishing, Oxford.

Lin, Y. H., Chen, K. S., Liou, T. D., Huang, J. W., \& Chang, P. F. L. (2009). Development of a molecular method for rapid differentiation of watermelon lines resistant to Fusarium oxysporum f. sp. niveum. Botanical Studies, 50, 273-280. https://doi.org/10.1016/j.nbt.2010.05.005

Mao, W., Lewis, J. A., Hebber, P. K., \& Lumsden, R. D. (1997). Seed treatment with a fungal or a bacterial antagonist for reducing corn damping-off caused by species of Pythium and Fusarium. Plant Disease, 81, 450-454. https://doi.org/10.1094/PDIS.1997.81.5.450

Martyn, R. D. (2012). Fusarium wilt of watermelon: A Historical review. In: Cucurbitaceae 2012, Proceedings of 
the 10th EUCARPIA meeting on genetics and breeding of Cucurbitaceae

Martyn, R. D., \& McLanghlin, R. J. (1983). Effects of inoculum concentration on the apparent resistance of watermelons to Fusarium oxysporum f.sp. niveum. Plant Disease, 67, 493-495. https://doi.org/10.1094/PD-67-493

Meyer, S. L. F. Everts Kathryne L., Gardener B. M., Masler, E. P., Abdelnabby, H. M. E., \& Skantar, A. M. (2016). Assessment of DAPG-producing Pseudomonas fluorescens for management of meloidogyne incognita and Fusarium oxysporum on watermelon. Journal of Nematology, 48(1), 43-53

Montealegre, J. R., Reyes, R., Perez, L. M., Herrera, R., Silva, P., \& Besoain, X. (2003). Selection of bioantagonistic bacteria to be used in biological control of Rhizoctonia solani in tomato. Electronic Journal of Biotechnology, 6, 115-127. https://doi.org/10.2225/vol6-issue2-fulltext-8

Nishimura, N. (2007). Selective media for Fusarium oxysporum. Journal of General Plant Pathology, 73, 342-348. https://doi.org/10.1007/s10327-007-0031-y

Notz, R., Maurhofer, M., Dubach, H., Haas, D., \& Defago, G. (2002). Fusaric acid-producing strains of Fusarium oxysporum alter 2,4-Diacetylphloroglucinol biosynthetic gene expression in Pseudomonas fluorescens $\mathrm{CHA} 0$ in vitro and in the rhizosphere of wheat. Applied Environmental Microbiology, 68, 2229-2235. https://doi.org/10.1128/AEM.68.5.2229-2235.2002

O'Sullivan, D. J., \& O'Gara, F. (1992). Traits of Fluorescent pseudomonas spp. involved in suppression of plant root pathogens. Microbiology Review, 56(4), 662-676

Peng, J., Zhan, Y., Zeng, F., Long, H., Pei1, Y. \&, Guo, J. (2013). Development of a real-time Fluorescence Loop-Mediated Isothermal amplification assay for rapid and quantitative detection of Fusarium oxysporum f. sp. niveum in Soil. FEMS Microbiology Letters, 349, 127-134. https://doi.org/10.1111/1574-6968.12305

Ren, Y., Jiao, D., Gong, G., Zhang, H., Guo, S., Zhang, J., \& Xu, Y. (2015). Genetic analysis and chromosome mapping of resistance to Fusarium oxysporum f. sp. niveum (FON) race 1 and race 2 in watermelon (Citrullus Lanatus L.). Molecular Breeding, 35, 183. https://doi.org/10.1007/s11032-015-0375-5

Reuveni, R. (1995). Novel approaches to integrated pest management. Lewis Publishers, CRC Press Inc., Boca Raton, FL.

Salman, M. (2010). Determination of antibiotic activity on plasmids from Fluorescent pseudomonads isolates CW2, WB15 and WB52 against pre emergence damping-off caused by Pythium ultimum and Rhizoctonia solani in cucumber. Biological Control, 53(2), 161-167. https://doi.org/10.1016/j.biocontrol.2010.01.007

Tu, C. C., \& Chang, Y. H. (1983). Soil microbial activity in relation to Fusarium wilt suppression soils and conducive soil. In: Proc Republic of China-Federal Republic of Germany Seminar Plant Nutrition Soil Sciences. National Science Council, Taipei, pp 189-196

Vogt, W., \& Buchenauer, H. (1997). Enhancement of biological control by combination of antagonistic fluorescent Pseudomonas isolates and resistance inducers against damping-off and powdery mildew in cucumber. Journal of Plant Diseases and Protection, 104(3), 272-280.

Walsh, U. F., Morrissey, J. P., \& O'Gara, F. (2001). Pseudomonas for biocontrol of phytopathogens: from functional genomics to commercial exploitation. Current Opinion in Biotecholgy, 12, 289-295. https://doi.org/10.1016/S0958-1669(00)00212-3

Weller, D. M. (1988). Biological control of soilborne plant pathogens in the rhizosphere with bacteria. Annual Review of Phytopathology, 26, 379-407. https://doi.org/10.1146/annurev.py.26.090188.002115

Zhang, Z., Zhang, J., Wang, Y., \& Zheng, X. (2005). Molecular detection of Fusarium oxysporum f. sp. niveum and Mycosphaerella melonis in infected plant tissues and soil. FEMS Microbiology Letters, 249 (2005) 39-47. https://doi.org/10.1016/j.femsle.2005.05.057

\section{Copyrights}

Copyright for this article is retained by the author(s), with first publication rights granted to the journal.

This is an open-access article distributed under the terms and conditions of the Creative Commons Attribution license (http://creativecommons.org/licenses/by/3.0/). 